\title{
Development of Site Characterization Technologies for Crystalline Rocks at Mizunami Underground Research Laboratory (MIU) - Surface-based Investigation Phase -
}

\section{미즈나미 지하처분연구시설 결정질암에 대한 부지 특성규명 기술 개발 -지표기반 조사단계-}

Katsuhiro Hama

Japan Atomic Energy Agency, Yamanouchi, Akiyo-cho, Mizunami-city, Gifu Pref., 509-6132, Japan

하마다 카츠히로

일본원자력연구개발기구, 일본 기후현 미즈나미시 아키요쵸 야마노우치 1-64

(Received May 22, 2012 / Revised August 27, 2012 / Approved April 9, 2013)

The Mizunami Underground Laboratory (MIU) Project is a comprehensive research project investigating the deep underground environment within crystalline rock being conducted by Japan Atomic Energy Agency. The MIU Project has three overlapping phases: Surface-based Investigation phase (Phase I), Construction phase (Phase II), and Operation phase (Phase III), with a total duration of 20 years. The overall project goals of the MIU Project from Phase I through to Phase III are: 1) to establish techniques for investigation, analysis and assessment of the deep geological environment, and 2) to develop a range of engineering for deep underground application. For the overall project goals 1), the Phase I goals were set to construct models of the geological environment from all surface-based investigation results that describe the geological environment prior to excavation and predict excavation response. For the overall project goals 2), the Phase I goals were set to formulate detailed design concepts and a construction plan for the underground facilities. This paper introduces geosynthesis procedures for the investigation and assessment of the hydrochemistry of groundwater in crystalline rock.

Key words: Mizunami Underground Research Laboratory, Site characterization technology, Groundwater Chemistry

미즈나미 지하처분연구시설 프로젝트는 일본원자력연구개발기구가 결정질암 내의 심부 지하 환경에 관해 종합적으로 연구 하는 프로젝트이다. 미즈나미 프로젝트는 3개의 중첩되는 단계로 구성된다: 지표기반 조사단계 (단계 1), 건설단계 (단계 2), 운영단계 (단계 3)의 총 20년. 미즈나미 프로젝트의 1단계에서 3단계까지의 전체 목표는 1) 심부지질환경을 조사, 분석, 평 가하기 위한 기술 정립, 2) 심부 지하 활용을 위한 일련의 공학적 기술 개발이다. 전체 목표 1 을 달성하기 위하여, 1 단계 목표 를 굴착 전에 지질환경을 모사하고 굴착거동을 예측하는 모든 지표기반 조사결과로부터 지질환경 모델을 구축하는 것으로 설정하였다. 전체 목표 2 를 달성하기 위하여, 2 단계 목표는 지하시설을 위한 상세 설계 개념과 건설 계획을 수립하는 것으 로 설정하였다. 본 논문은 결정질암내 지하수의 수리지화학적 특성을 조사하고 평가하기 위한 지질통합적 방법을 소개한다.

중심단어 : 미즈나미 지하처분연구시설, 부지 특성규명 기술, 지하수 수리지화학

E-mail: hama.katsuhiro@jaea.go.jp, Tel: +81.572.66.2244 
Katsuhiro Hama. : Development of Site Characterization Technologies for Crystalline Rocks at Mizunami Underground Research Laboratory (MIU) - Surface-based Investigation Phase -

\section{Introduction}

The Mizunami Underground Laboratory (MIU) Project is a comprehensive research project investigating the deep underground environment within crystalline rock being conducted by Japan Atomic Energy Agency at Mizunami City in Gifu Prefecture, central Japan and its role is defined in "Framework for Nuclear Energy Policy" by Japan Atomic Energy Commission. The MIU Project has three overlapping phases: Surfacebased Investigation phase (Phase I), Construction phase (Phase II), and Operation phase (Phase III), with a total duration of ca. 20 years. Phases are overlapped phase by phase. The overall project goals of the MIU Project from Phase I through to Phase III are: 1) to establish techniques for investigation, analysis and assessment of the deep geological environment, and 2) to develop a range of engineering for deep underground application. During Phase I, the overall project goals were supported by Phase I goals. For the overall project goals 1), the Phase I goals were set to construct models of the geological environment from all surface-based investigation results that describe the geological environment prior to excavation and predict excavation response. For the overall project goals 2), the Phase I goals were set to formulate detailed design concepts and a construction plan for the underground facilities. This paper summarizes the Phase I investigation which was completed in March 2005.

With regard to the overall project goals 1 ), "To establish techniques for investigation, analysis and assessment of the deep geological environment", a step-wise investigation was conducted by iterating investigation, interpretation, and assessment, thereby understanding of geologic environment was progressively and effectively improved with progress of investigation. An optimal procedure from investigation to assessment was compiled as a set of geosynthesis data flow diagrams for each investigation step. With regard to the overall project goals 2), "To formulate detailed design concepts and a construction plan for the underground facilities", an optimal design of MIU was completed

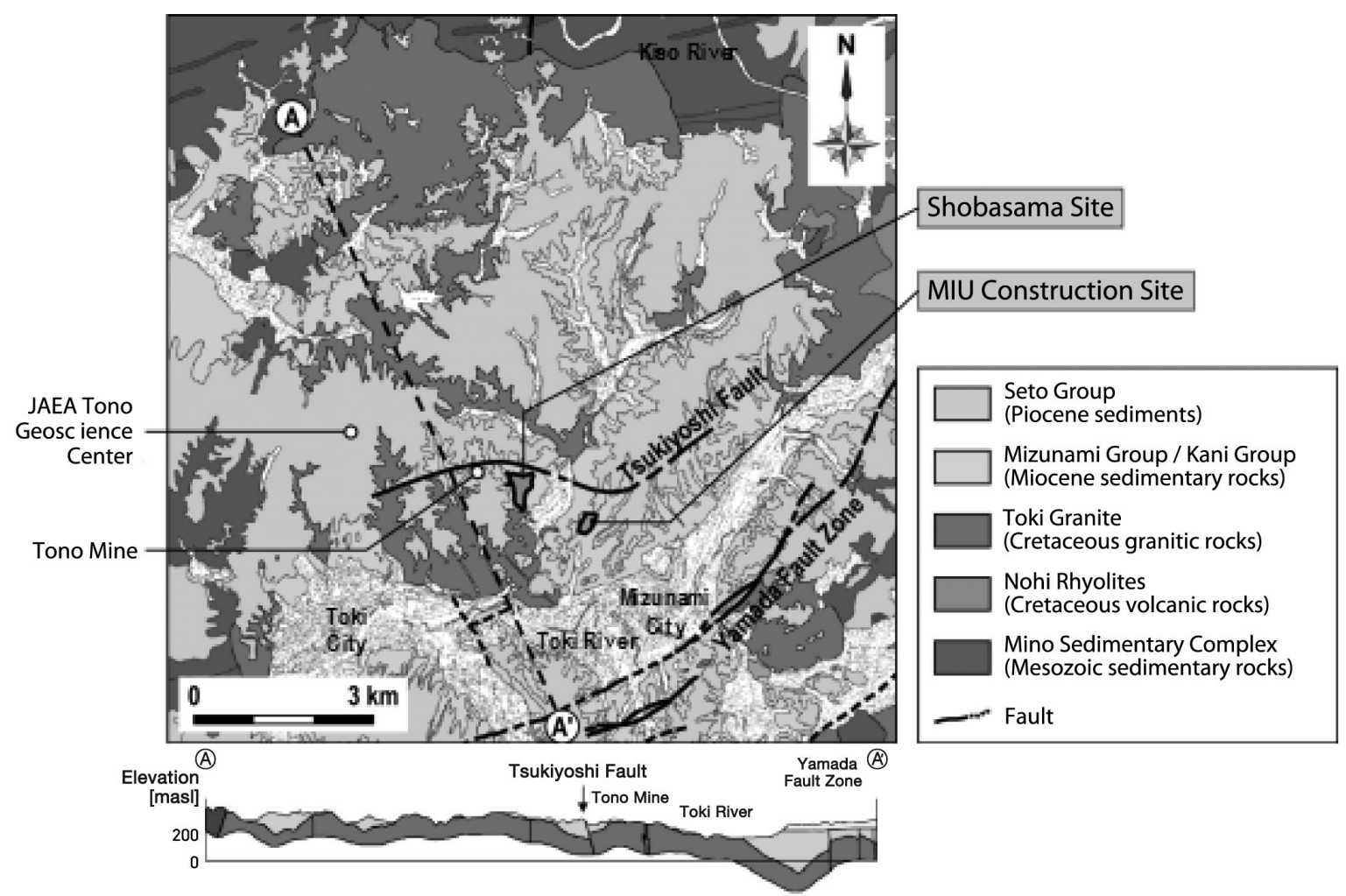

Fig. 1. Geological map and geological section of the Tono area. 
with the aim to provide a foundation for engineering technologies in deep underground to safely construct and operate an underground facility which will be built for the purpose of acquiring data and demonstrating disposal technologies.

\section{History of the MIU project}

The geology around the MIU site consists of Cretaceous granite (Toki Granite) basement rock overlain by Miocene-Neogene sediments (Mizunami Group) and less consolidated Pliocene-Neogene gravel layers (Seto Group) (Fig. 1). The underground facilities will be constructed mainly in the Toki Granite basement (Fig. 2). Topographically, the Tono area, where the MIU is located, is hilly land bounded by the Mino-Hida Mountains to the north-west and Mikawa Mountains to the

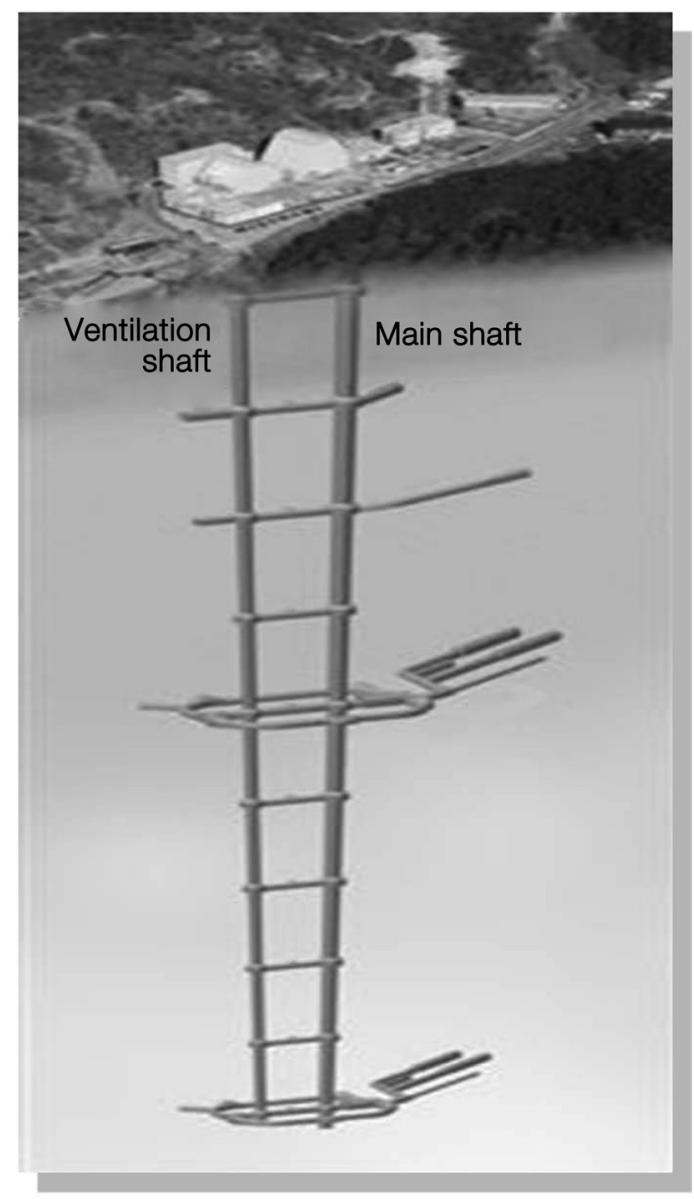

Fig. 2. Planned layout of the MIU facilities (plan at the end of Phase I investigation). south-east. In the mountainous area to the north, the antecedent Kiso River forms a deep valley. In the central part of the area, the Toki River flows from northeast to south-west. Terraces developed along the Toki River and its tributaries form platforms and alluvial deposits extend into the lowlands along the river.

The MIU project was initiated in 1996 at the JAEAowned Shobasama site at Mizunami in Gifu Prefecture under an agreement between the local governments of Gifu Prefecture, Mizunami City, Toki City and JNC (now JAEA), with the approval of the Science and Technology Agency (now the Ministry of Education, Culture, Sports, Science and Technology) signed in December 1995, entitled "Agreement on Geoscientific Research at the Tono Geoscience Center".

In January 2002, JAEA and Mizunami City concluded a lease contract for city-owned land at Akeyo in Mizunami, finalizing the decision to construct the underground facilities and related installations of the MIU project at this location. Preparation of the land for the project began in parallel with the Phase 1 investigations in July 2002, with excavation of the shaft basement in July 2003, followed by full excavation work for the shaft in 2004. The Phase I investigations at the MIU site extended over three years from 2002 to 2004.

\section{Overview of the Phase I investigations}

\subsection{Goals}

The goals of Phase I of the MIU project are:

(1) Constructing geological models based on the results of surface-based investigations and determining the conditions of the deep geological environment prior to the excavation of the underground facilities.

(2) Completing the detailed design for the underground facilities and formulation of the construction plan.

(3) Formulation of an investigation program for the construction phase.

\subsection{Specific aims and items}

The function of the geological environment in the 
Katsuhiro Hama. : Development of Site Characterization Technologies for Crystalline Rocks at Mizunami Underground Research Laboratory (MIU) - Surface-based Investigation Phase -

repository concept includes physical isolation of the waste for long time periods, providing a suitable environment for the emplacement of the engineered barriers and natural barrier capability. The requirements on the geological environment in terms of physically isolating waste for a long time period have been listed by Nuclear Waste Management Organization of Japan (NUMO) as Siting Factors for the Selection of Preliminary Investigation Areas [1].

In order to ensure the technical feasibility and safety of geological disposal (in addition to meeting environmental requirements), the geological environment in question has to fulfill the conditions and functions de- scribed below:

- Distribution at a suitable depth and sufficient spatial extent for the construction of a repository (ensuring the required rock volume for geological disposal)

- Virtually homogeneous stress conditions and low temperatures in the geological formations of interest, with a view to ensuring safe design and construction and maintaining the integrity of the engineered barriers and disposal facilities

- Low groundwater flux, moderately alkaline and reducing groundwater chemistry, with a view to restricting erosion of the buffer material, overpack
Important factors to be characterized

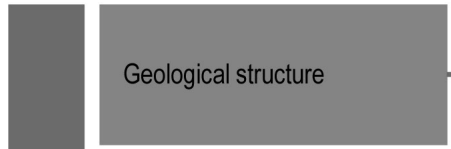

Groundwater flow characteristics
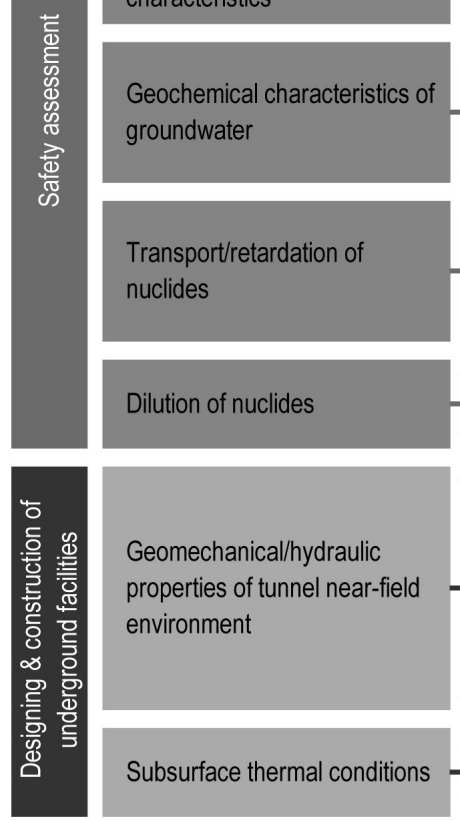

Subsurface thermal conditions

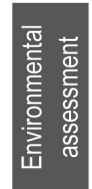

Data requirements

Size and geometry of host rock; heterogeneity within host rock Size and extent of surrounding formations

Spatial distribution and geometry of transport pathways (groundwater flowpaths)

Spatial variability of magnitude of hydraulic gradient

Spatial variability of hydraulic properties of rocks

Redox conditions
Spatial variability of groundwater $\mathrm{pH}$ values

Spatial distribution of different groundwaters; degree of groundwater mineralization

$\left[\begin{array}{l}\text { Sorption capacity and diffusivity of rock matrix and of transport pathways } \\ \text { Geometry of transport pathways; depth of diffusion-accessible rock matrix } \\ \text { Effect of colloid/organics/microbes on nuclide transport/retardation }\end{array}\right.$

Spatial distribution of higher-permeability rocks, aquifers and surface waters

Spatial variability of water fluxes in higher-permeability rocks, aquifers and surface waters

Local stress regime
Spatial variability of petrophysical/geomechanical properties of rocks
Volume of inflow into underground tunnels
-Size and structure of EDZ; petrophysical/geomechanical properties of EDZ
Distribution of discontinuities intersecting underground tunnels

Spatial variability of geothermal gradient

Thermal rock properties

Environmental impact induced
by construction of underground
facilities $\left\{\begin{array}{l}\text { Impact on water table } \\ \text { Impact on hydraulic pressure } \\ \text { - Impact on groundwater chemistry } \\ \text { Effects of noise and vibration }\end{array}\right.$

Fig. 3. List of important factors to be characterized and data requirements, relevant to safety assessment, designing/construction of underground facilities and environmental assessment. 
Katsuhiro Hama. : Development of Site Characterization Technologies for Crystalline Rocks at Mizunami Underground Research Laboratory (MIU) - Surface-based Investigation Phase -

corrosion and glass dissolution

- Slow groundwater flow, long transport paths and sufficient retardation of radionuclide transport in order to restrict nuclide migration

- Large dilution/dispersion of radionuclides, thus reducing concentrations.

The geological environment of interest is thus required to provide a suitable environment for the emplacement of the engineered barriers and to function as a natural barrier for a long period of time. During the Phase I investigations, the conditions and functions of the geological environment that are important for geological disposal were identified (Fig. 3). Reference was made in this context to international generic FEP - Features, Events and Processes - lists of investigation items for the preliminary investigations.

For the MIU project, the information on the geological environment obtained through the investigations in Phase I will be used in the design and construction of the underground facilities. The features and processes of the geological environment to be investigated should therefore also be reviewed from the viewpoint of design and construction. In recent years, increasing em- phasis has been placed on the importance of evaluating not only the safety of the human environment but also the social and environmental impacts of geological disposal projects ([2], [3], [4]). Environmental impact assessments are therefore considered to be important, as is the case for large-scale projects such as tunnel excavation and construction of dams.

\subsection{Spatial scales}

Setting spatial scales is a key issue in effectively understanding the geological environment and its heterogeneity based on limited number of investigations. This should be done bearing in mind the need to reflect the results of the research in the safety assessment and in the design and construction of the underground facilities. The regional hydrological study and the MIU project adopt a stepwise approach to characterize the geological environment based on surface-based investigations and to evaluate groundwater flow and mass transport behavior, focusing on groundwater flow system extending from the recharge area to discharge area and including the URL site and layout of the underground facilities. Therefore, four spatial scales were

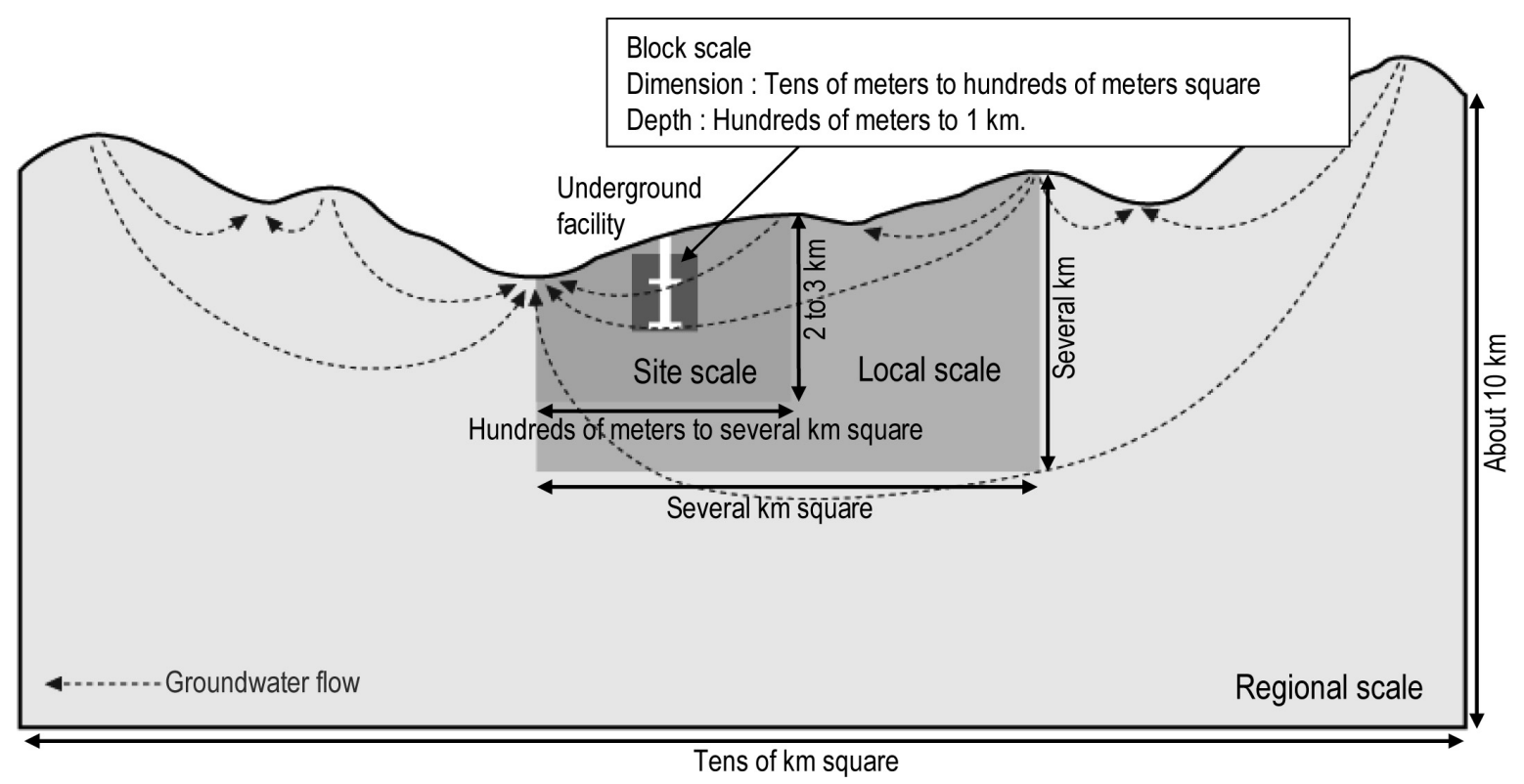

Fig. 4. Concept of scale. 
Katsuhiro Hama. : Development of Site Characterization Technologies for Crystalline Rocks at Mizunami Underground Research Laboratory (MIU) - Surface-based Investigation Phase -

used for the investigations as shown in Fig. 4: regional, local, site and block scale.

\subsection{Iterative approach}

Various spatial, temporal and financial limitations are likely to be encountered when characterizing the geological environment at specific sites. To allow effective investigations under these conditions, the relationship between the types and volume of information obtained during the investigations, the level of understanding and the results of the investigations should be evaluated at each stage. The results should then be reflected in the planning of specific investigation programs in the subsequent stages on the one hand and in the decisions made when proceeding to the next stage on the other hand. The approach used for this is the iterative approach as shown in Fig. 5. The iterative approach consists of eight major steps:

(1) Developing and updating the geological environment concept: Based on the information on geological characteristics obtained from investigations and analyses in the preceding loop, geological structures and characteristics relevant to geological disposal that could affect groundwater flow and groundwater chemistry are identified in order to conceptualize the geological environment in the area of interest.

(2) Formulating and updating the program: Based on the concept developed for the geological environment, specific goals and issues for investigation and the concept of spatial scales, as well as the details of the investigation program, will be formulated and revised appropriately.

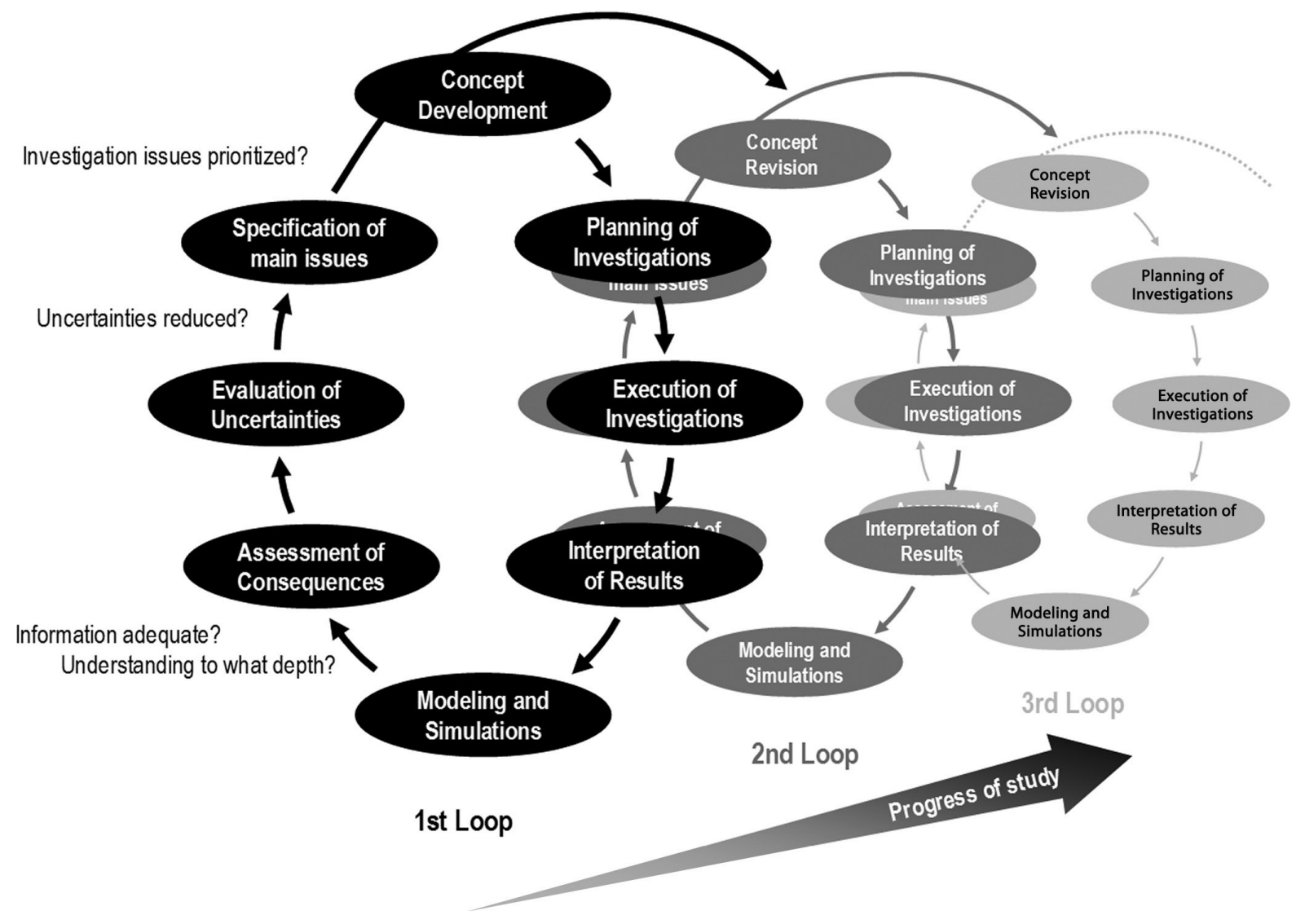

Fig. 5. Iterative approach for the characterization of geological environment. 
Katsuhiro Hama. : Development of Site Characterization Technologies for Crystalline Rocks at Mizunami Underground Research Laboratory (MIU) - Surface-based Investigation Phase -

(3) Performing investigations: Performing investigations according to the investigation program.

(4) Interpretation of data: Referring to the specified goals and issues, data from the investigations are interpreted and used as inputs for modeling/analyses and the spatial distributions and uncertainties associated with the data are analyzed.

(5) Modeling/analyses: Based on the results of interpreting the data (e.g. datasets), geological, hydrogeological, geochemical, rock mechanical and mass transport models are developed. Since the specific goals of the investigations in question will differ depending on the investigation step, the objectives for modeling/analyses will be determined for each investigation step. Using the developed geological models, the evolution of groundwater flow and groundwater chemistry with time will be predicted.

(6) Evaluation of analysis results: Discussion of the re- sults obtained from modeling/analyses. In particular, the consistency of the results among models using different data should be examined. Through modeling and analysis, it can also be evaluated whether sufficient information on geological characteristics has been obtained with respect to the specified goals of the investigations or in what detail the geological environment of interest has been understood or described.

(7) Evaluation of uncertainties: Quantifying the results of the analysis and translating them into objective and transparent information. In order to improve the validity and reliability of the results of modeling/analyses in terms of the specific goals and issues defined for the investigations, it is necessary to quantify the uncertainties arising due to different data quality, interpretations and modeling in order to demonstrate how much the uncertainties have

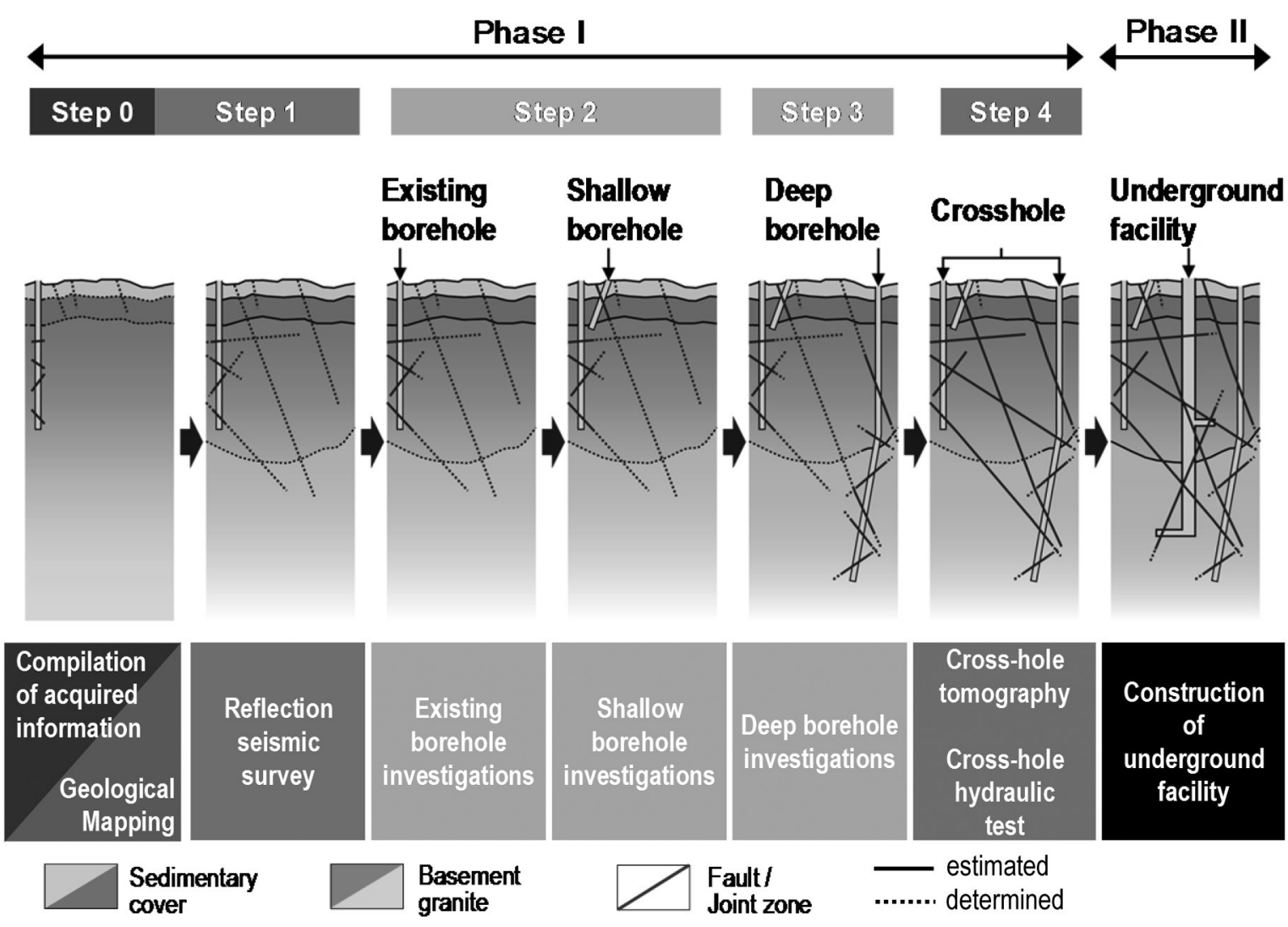

Fig. 6. Concept of Phase I investigations. 
Katsuhiro Hama. : Development of Site Characterization Technologies for Crystalline Rocks at Mizunami Underground Research Laboratory (MIU) - Surface-based Investigation Phase -

been reduced.

(8) Identification of key factors: Based on the results of (1) through (7) above, key factors for achieving specific goals and issues will be identified as issues to be addressed in the subsequent loop.

Based on the knowledge accumulated through a series of loops of iterative approach, applicability of comprehensive techniques for investigation, analysis and assessment of the geological environment, which is adopted on the MIU Project, are confirmed. Then, comprehensive techniques are optimized.

\subsection{Strategy for the surface-based investiga- tions in Phase I}

The investigations at the MIU Construction Site during Phase I followed the sequence of: preliminary characterization of the geological environment on wider area using techniques providing 2D information; identification of open issues requiring more detailed information; borehole investigations addressing the investigation items. Investigations were scheduled so that interactions among drilling or testing of borehole could be avoided. More specifically, investigations were categorized into five steps as shown in Fig. 6. In each investigation step, investigations were carried out according to the geosynthesis data flow diagram [5], [6] and following the iterative approach. The geosynthesis data flow diagram illustrates, for the specific aims, the types and combinations of investigations to be carried out, the types of data to be acquired, interpretation of data and synthesis of the information obtained in the different disciplines. In each step, models of geological environment were developed integrating the latest information and items to be addressed in the subsequent step were identified. Thus, by adopting the sequence described above, the relationship between type and quantity of the investigations, and the level of understanding regarding specific aims was made clear.
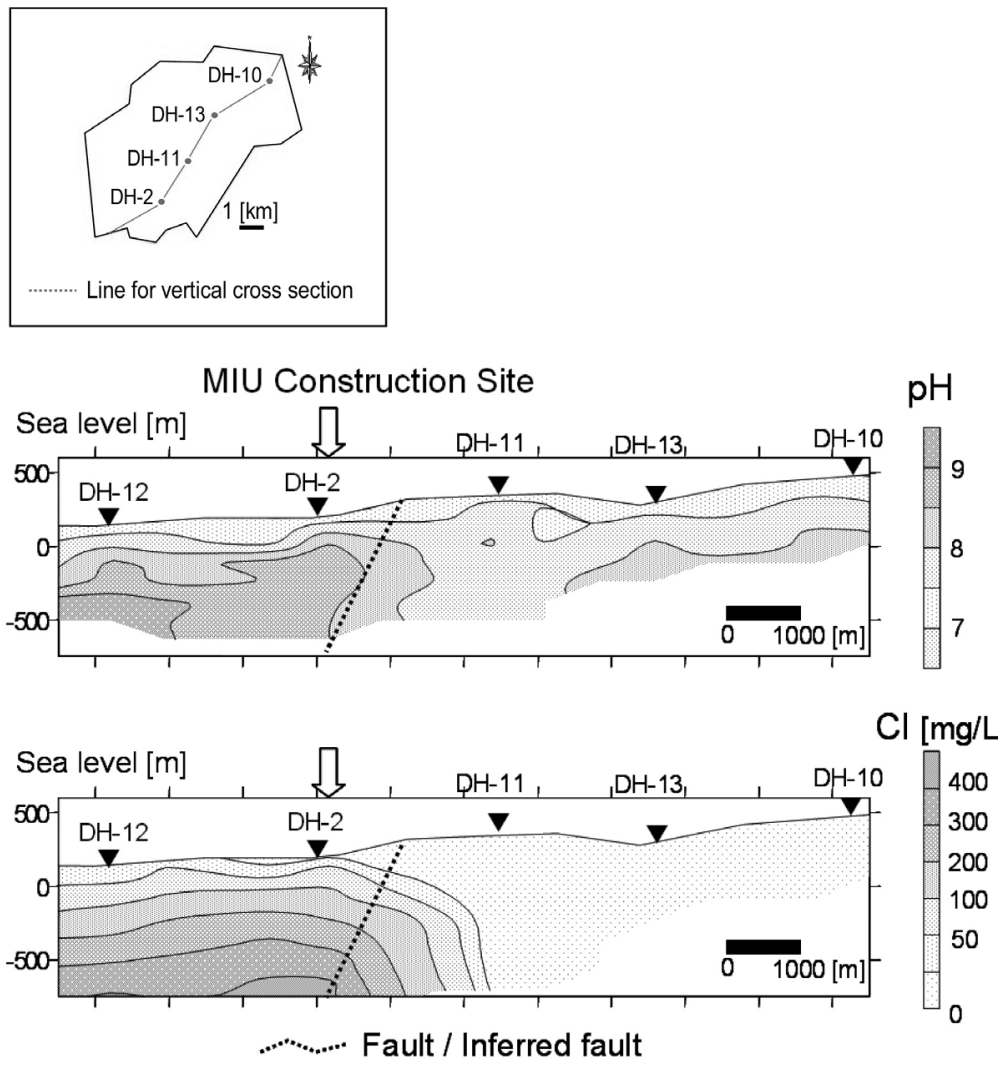

*DH: location of deep borehole

Fig. 7. Estimated distribution of groundwater chemistry ( $\mathrm{pH}$ and $\mathrm{Cl}$ content). 
Katsuhiro Hama. : Development of Site Characterization Technologies for Crystalline Rocks at Mizunami Underground Research Laboratory (MIU) - Surface-based Investigation Phase -

Specifically, based on compilation of acquired information (Step 0), the characteristics of geological environment related to specific aims, such as 3D distribution of geological structures, groundwater flow characteristics and groundwater geochemistry in the site scale area, were roughly understood. The acquired information included information obtained from literature surveys and investigations carried out at the Shobasama Site before the Project on the MIU Construction Site started. The locations of lithological boundaries and discontinuities were then estimated two dimensionally by detailed surface geological mapping and reflection seismic surveys (Step 1), and borehole investigations were used to characterize all lithofacies and discontinuities (Steps 2 and 3). Ideally, the borehole investigations should have been conducted in series, i.e. investigations in existing borehole, new shallow borehole investigations and new deep borehole investigations. However, because the time for commencing shaft excavation had already been decided, investigations in existing borehole and new shallow borehole investigations (Step 2) were conducted in parallel, i.e. these two borehole investigations were combined to form one step. The locations and geometry of discontinuities, their hydrological characteristics and their continuity in the area between boreholes were determined by crosshole tomography and crosshole hydrological tests (Step 4).

\section{Results from the Phase I investigations}

Geological, hydrogeological, hydrochemical and rock mechanical investigations and modeling have been carried out during Phase I. In this chapter, detailed results of hydrochemical investigations are described as an example.

Step-wise approach was applied for hydrochemical investigation in and around the MIU construction site. Hydrochemical investigations are carried out in step 0 (surveys of existing information), in step 2 (surveys in existing boreholes and new shallow borehole investigations) and also in step 3 (new deep borehole investigations).

\subsection{Step 0 (Surveys of existing information)}

For the local-scale area, data on groundwater chemistry, $\mathrm{pH}$ and redox conditions had been obtained mainly from borehole investigations carried out as part of the regional hydrogeological study. Using these data, the spatial distribution of the hydrochemical characteristics of the groundwater between the boreholes and in the site-scale area were estimated using the kriging method. It was indicated that, on the south side of the site-scale area, the groundwater in the granite was Na$\mathrm{Cl}$ type, the concentration of chloride ions increases with depth, the $\mathrm{pH}$ of the groundwater was mildly alkaline (Fig.7) and the redox conditions were estimated to be weakly to strongly reducing. Mass balance analysis and multivariate analysis indicate that the chemistry of the groundwater in the site-scale area could be explained by the mixing of several groundwaters with different salinities. One of the main processes determining groundwater chemistry was thus identified as being the mixing of groundwaters with different salinities.

$\mathrm{Na}-\mathrm{Ca}-\mathrm{Cl}$ type groundwater with a salinity of several thousand $\mathrm{mg} 1^{-1}$ has been pumped from a depth of around 1,300 $\mathrm{m}$ at a hot spring (Takasago hot spring in Mizunami City) located $3 \mathrm{~km}$ south-east of the sitescale area [7]. The data from this hot spring were not included in Fig. 7 because their quality is not clear. In this figure, data on groundwater chemistry in borehole DH-2 (located at the vicinity of boundary of the MIU Construction Site) collected down to a depth of $500 \mathrm{~m}$ were used and the distribution of groundwater chemistry in the zone deeper than $500 \mathrm{~m}$ was therefore uncertain. Thus, Na-Ca-Cl type groundwater with salinities higher than the estimated level (a few thousand $\mathrm{mg} 1^{-1}$ ) shown in Fig. 7 may be present deep underground in the site-scale area. Investigation of the distribution of $\mathrm{Na}-\mathrm{Ca}-\mathrm{Cl}$ type groundwater was identified as an important issue to be addressed in Step 1 and subsequent steps.

For the areas where high-salinity groundwater is present and a depth dependence of the concentration is seen, the evolution process of groundwater chem- 
Katsuhiro Hama. : Development of Site Characterization Technologies for Crystalline Rocks at Mizunami Underground Research Laboratory (MIU) - Surface-based Investigation Phase -

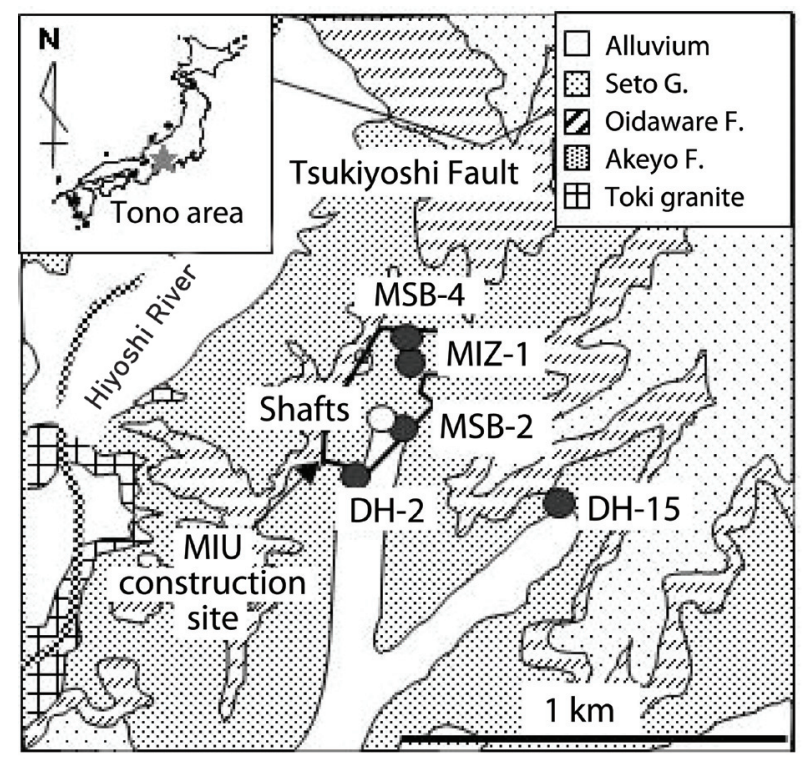

Fig. 8. Borehole layout in and around the MIU construction site.
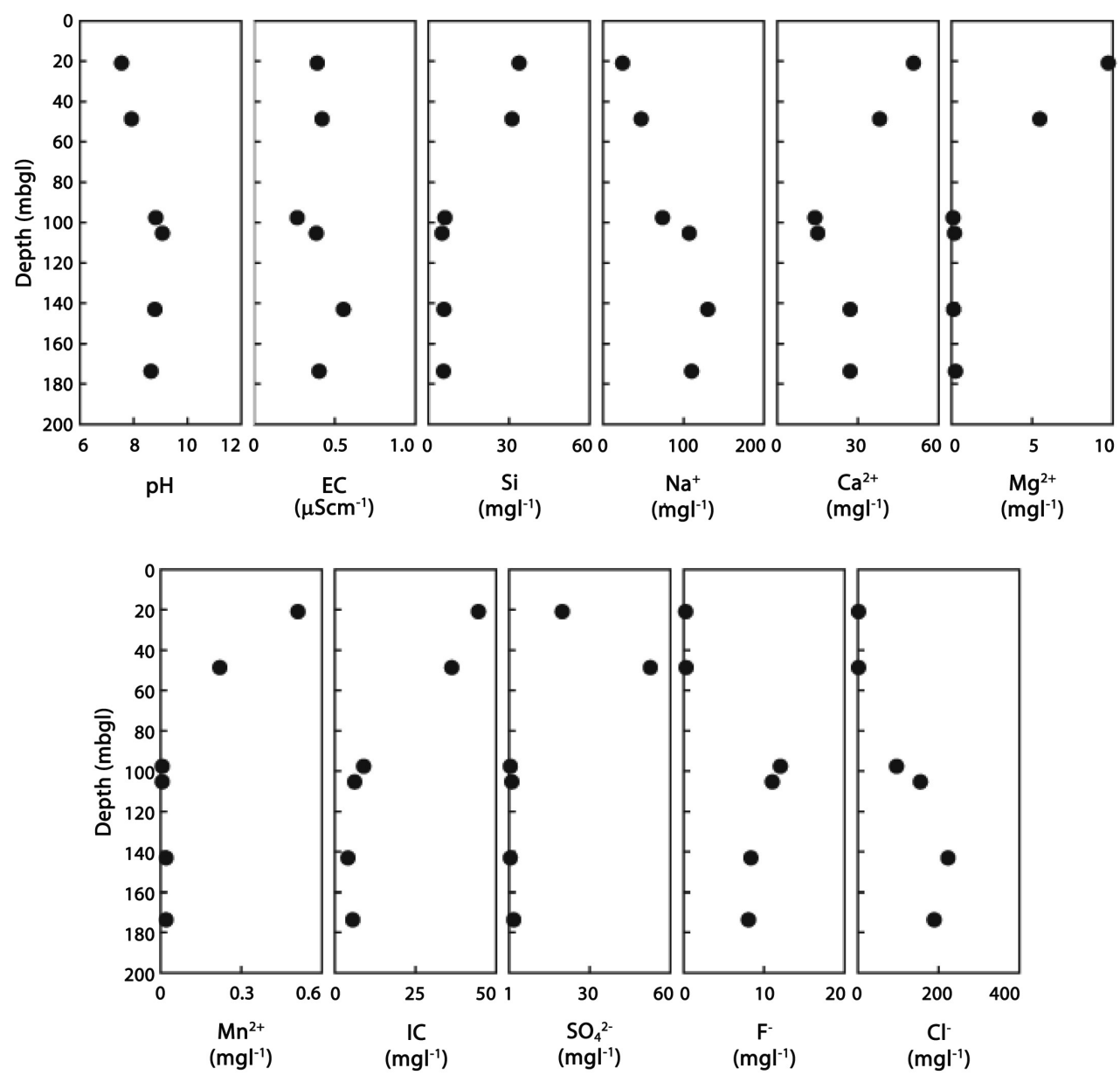

Fig. 9. Depth profile of groundwater chemistry in the borehole (MSB-2, 4). 
istry (e.g. mixing of groundwaters with different salinity) could be ascertained from 2-D distributions of the groundwater chemistry calculated with the kriging method, mass balance analysis and multivariate analysis.

\subsection{Step 2 (shallow borehole investigations)}

The goals of the investigations in this step were to test and update the hydrochemical model and to determine the geological environment prior to the excavation of the underground facilities, based on the data and the analysis results obtained in Steps 0 and 1. Since geochemical data of the groundwater of sedimentary formations around the MIU Construction Site had not been measured up to this point, this step aimed to acquire these data. Therefore, groundwater and rock samples were collected and analyzed for hydrochemical analysis and for updating the model, by conducting borehole investigations for the Mizunami Group with a thickness of a few tens of meters to approximately 200 meters, covering the Toki Granite.

Groundwater samples were collected from three boreholes (MSB-2, 4, DH-2) (Fig.8) by using a single or multi packer system. The MSB-2 and 4 boreholes were drilled to the unconformity between sedimentary rock and basement granite at depths of approx. 100 200 mbgl. In contrast, DH-2 focus mainly on the basement granite up to $500 \mathrm{mbgl}$. These 3 boreholes are located in the vicinity of the shafts. Other than DH-2, the boreholes were drilled in 2002-2004 using drilling fluid with tracers (fluorescence dyes such as uranine, amino G. acid, eosin) to obtain quality-controlled drilling fluid-contaminated samples. $\mathrm{DH}-2$ had been drilled without any tracer during hydraulic investigations in 1993-1994. Then, after "open-borehole" conditions for 10 years, the groundwater samples were collected by hydraulic pumping tests in 2002. During sampling campaigns, groundwater with drilling fluid was pumped out from the section isolated single or double packers. Tracer concentrations continuously decreased as the drilling fluid was pumped out. The chemical com- positions ( $\mathrm{Si}, \mathrm{Na}, \mathrm{K}, \mathrm{Mg}, \mathrm{Ca}, \mathrm{F}, \mathrm{Cl}, \mathrm{Br}, \mathrm{NO}_{3}, \mathrm{SO}_{4}, \mathrm{I}$, TC: Total Carbon, TOC: Total Organic Carbon, DIC: Dissolved inorganic Carbon, Alkalinity) of the groundwater were analyzed at suitable intervals as the tracer decreased, to estimate in-situ chemical compositions without drilling fluid contamination. For the last sample obtained from each pumping test, the concentrations of $\mathrm{Sr}, \mathrm{HS}^{-}, \mathrm{NO}_{2}^{-}, \mathrm{NH}_{4}^{+}, \mathrm{Al}$, Total $\mathrm{Fe}, \mathrm{Fe}^{2+}$ and isotopic composition $\left({ }^{2} \mathrm{H} /{ }^{1} \mathrm{H}\right.$, tritium, $\left.{ }^{18} \mathrm{O} /{ }^{16} \mathrm{O},{ }^{13} \mathrm{C} /{ }^{12} \mathrm{C},{ }^{14} \mathrm{C}\right)$ were determined to estimate the origin, residence time and chemical evolution process of the groundwater.

The results of the above investigations indicated that the groundwater in the sedimentary rocks in the site-scale area is $\mathrm{Na}-\mathrm{Ca}-\mathrm{HCO}_{3}$ type, rich in silicon and sulphate ions in the shallower part and $\mathrm{Na}-\mathrm{Cl}$ type in the deeper part of the Mizunami Group and the upper part of the Toki Granite (Table 1, Fig. 9). It was also found that the salinity of the groundwater generally increases with increasing depth. A low permeability layer was found at the depth where the boundary occurs between the $\mathrm{Na}-\mathrm{Ca}-\mathrm{HCO}_{3}$ type and the $\mathrm{Na}-\mathrm{Cl}$ type groundwater in the Mizunami Group. Additionally, a significant lower hydraulic head was observed in the lower part of Mizunami group. The low permeable layer effectively separates the two different groundwater types (Fig.10). The origin and evolution process of $\mathrm{Na}-\mathrm{Ca}-\mathrm{HCO}_{3}$ type groundwater suggests meteoric water and water-rock interaction, respectively [8]. On the other hand, the origin and evolution process of $\mathrm{Na}-\mathrm{Cl}$ type groundwater is not clear. However, the origin of $\mathrm{Na}-\mathrm{Cl}$ type groundwater will be different from the Na$\mathrm{Ca}-\mathrm{HCO}_{3}$ type groundwater.

In the shallower part of the Mizunami Group, the hydrogen/oxygen isotope ratio in the groundwater varies within the fluctuation range of that in the precipitation water sampled around the MIU Construction Site (Table 1). Tritium was also detected. Thus, the origin of the groundwater in the shallower part of the Mizunami Group is considered to be recent precipitation, with a faster recharge rate compared to the groundwater in the deeper part of the Group [8]. This finding, combined with that in Step 0 , suggests that the flow rate of 
Katsuhiro Hama. : Development of Site Characterization Technologies for Crystalline Rocks at Mizunami Underground Research Laboratory (MIU) - Surface-based Investigation Phase -

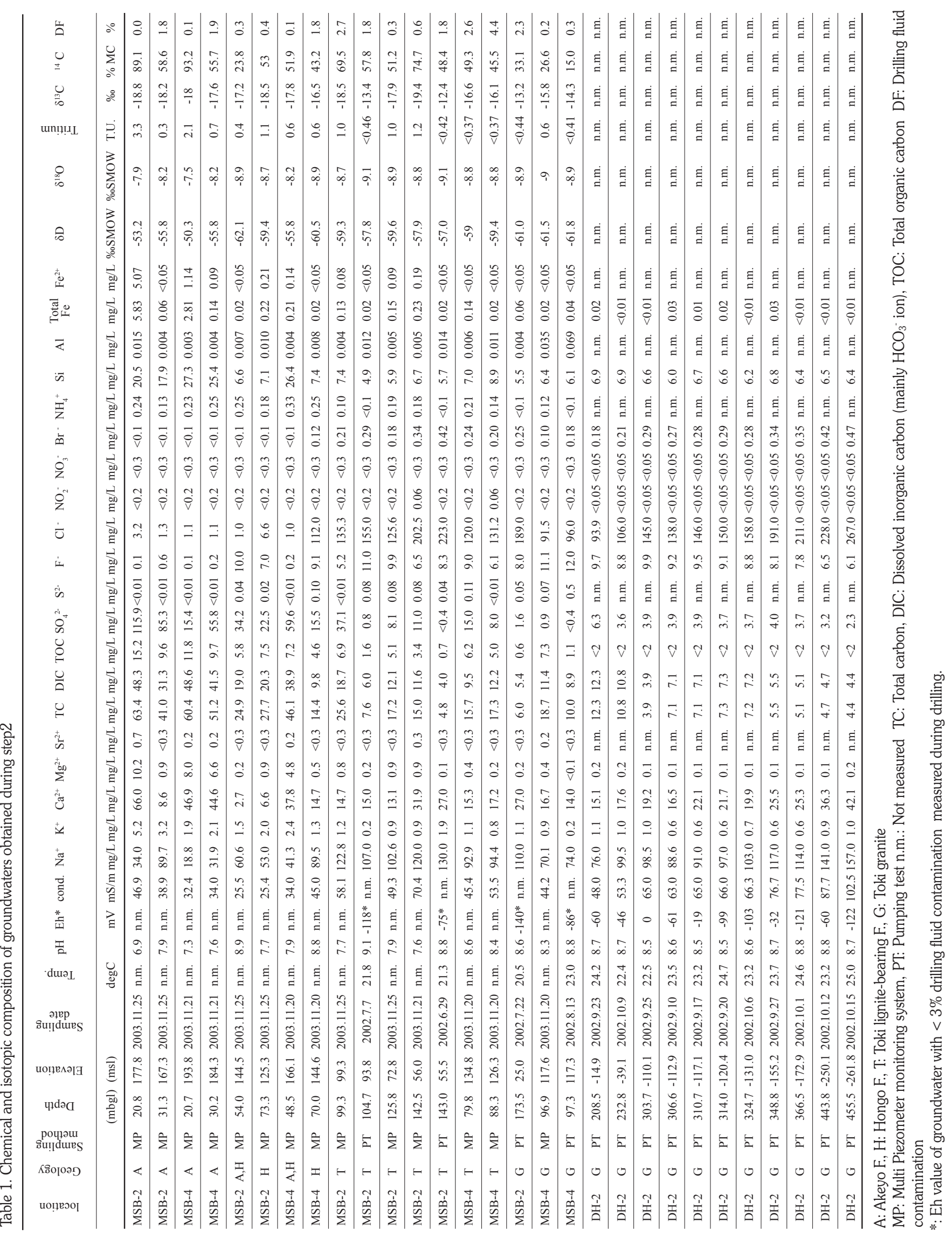


the groundwater would be very slow deep underground at the MIU Construction Site where it is surrounded by the the low permeability formations in the sedimentary rocks.

At the time of excavating the underground facilities, since the distribution of groundwater chemistry and groundwater flow conditions may have been affected by the distribution of the low permeability formations in the sedimentary rocks, the extent and level of their influence is expected to be different bordering at the low permeability formation. Therefore, observations and analyses for each hydrogeological unit would be essential for evaluating the change in the groundwater regime associated with the excavation in Phase II and subsequent phases. The geochemical characteristics of the groundwater in the Toki Granite would need to be reflected in the investigations using deep boreholes to be conducted in the next step.

In Step 2, information showing the relationship between the distribution of geochemical characteristics of groundwater chemistry and the hydrogeological structures in the Mizunami Group and the adequacy of the results of the groundwater flow analysis in Step 2 was acquired. Guidance for the investigations in the subsequent steps was also established e.g. clarification of the origin of the $\mathrm{Na}-\mathrm{Cl}$ type groundwater in the lower sedimentary formation. Comparison of the hydraulic characteristics with the distribution of geochemical characteristics of groundwater would allow the results of the groundwater flow analysis to be tested and the

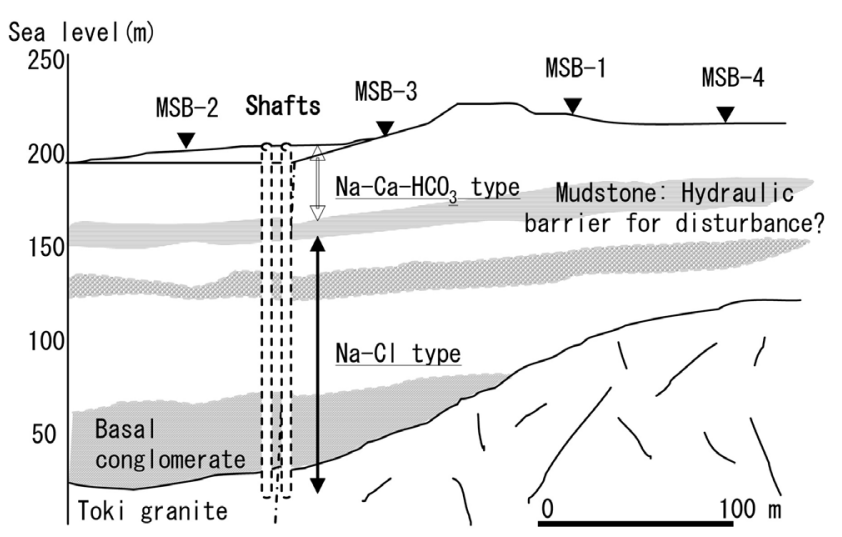

Fig. 10. Schematic view of groundwater chemistry in the sedimentary rock of site scale. credibility of the conceptual hydrochemical model to be improved. It was considered important to acquire data on the geochemistry of the groundwater in the granite during the investigations in the subsequent steps.

\subsection{Step 3 (deep borehole investigations)}

The objectives of the deep borehole investigations include determining the geochemical characteristics of the groundwater in the granite to a depth of approximately 1,000 meters prior to excavation of the underground facilities in order to incorporate the results in the initial conditions for the analyses of the influence of the excavation on the groundwater regime around the facility in Phase II and subsequent phases. A further objective is to determine geochemical characteristics of the groundwater encountered in the underground facilities as input for planning the investigations in Phase II. To this end, groundwater and rock samples were collected and analyzed and the hydrochemical model based on the investigation results from Step 2 and preceding steps was updated.

Groundwater samples were collected from two boreholes (DH-15 and MIZ-1) by using a single or multi packer system. MIZ-1 focuses mainly on the basement granite up to 1275 mbgl. DH-15, which was drilled to a depth of $1,000 \mathrm{mbgl}$, was drilled approx. $0.5 \mathrm{~km}$ away from the shafts (Table 1, Fig. 8). The boreholes were drilled in 2002-2004 using drilling fluid with tracers (fluorescence dyes such as uranine, amino G. acid, eosin) to obtain quality-controlled drilling fluidcontaminated samples. During sampling campaigns, groundwater with drilling fluid was pumped out from the section isolated single or double packers. Tracer concentrations continuously decreased as the drilling fluid was pumped out. The chemical compositions $(\mathrm{Si}$, $\mathrm{Na}, \mathrm{K}, \mathrm{Mg}$, $\mathrm{Ca}, \mathrm{F}, \mathrm{Cl}, \mathrm{Br}, \mathrm{NO}_{3}, \mathrm{SO}_{4}$, I, TC: Total Carbon, TOC: Total Organic Carbon, DIC: Dissolved inorganic Carbon, Alkalinity) of the groundwater were analyzed at suitable intervals as the tracer decreased, to estimate in-situ chemical compositions without drilling fluid contamination. For the last sample obtained from each pumping test, the concentrations of Sr, HS', $\mathrm{NO}_{2}{ }^{-}, \mathrm{NH}_{4}^{+}, \mathrm{Al}$, Total Fe, Fe ${ }^{2+}$ and isotopic compo- 
Katsuhiro Hama. : Development of Site Characterization Technologies for Crystalline Rocks at Mizunami Underground Research Laboratory (MIU) - Surface-based Investigation Phase -

\begin{tabular}{|c|c|c|c|c|c|c|c|c|c|c|c|c|c|c|}
\hline 㟔 & $\therefore$ & $\stackrel{\circ}{-}$ & तु่ & if & 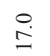 & $\stackrel{\text { gi }}{\mathrm{g}}$ & nू & $\vec{i}$ & $\stackrel{0}{0}$ & 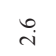 & is & $\stackrel{m}{F}$ & $\overrightarrow{8}$ & .0.0 \\
\hline$\underset{ \pm}{ \pm}$ & $\therefore \frac{0}{\Sigma}$ & 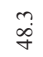 & 获 & $\frac{n}{n}$ & 今े & $\begin{array}{l}n \\
n \\
\infty \\
\infty\end{array}$ & ڤู & $\dot{q}$ & $\stackrel{0}{\stackrel{0}{\infty}}$ & $\stackrel{\circ}{\stackrel{0}{2}}$ & $\stackrel{\infty}{\dot{p}}$ & $\stackrel{g}{g}$ & $\stackrel{\partial}{\vec{F}}$ & $\stackrel{\infty}{\stackrel{\Xi}{*}}$ \\
\hline D. & $\alpha^{\&}$ & $\stackrel{n}{1}$ & घ: & $\stackrel{\infty}{=}$ & $\stackrel{m}{1}$ & $\stackrel{2}{1}$ & $\div$ & 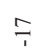 & $\stackrel{?}{1}$ & $\frac{1}{7}$ & $\overrightarrow{\dot{I}}$ & $\dot{g}$ & $\overline{\mathrm{I}}$ & D. \\
\hline unnب̣ı. & $\stackrel{\text { S. }}{\dot{H}}$ & $\hat{\tilde{v}}$ & घี & 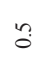 & $\tilde{\tilde{v}}$ & $\tilde{\hat{v}}$ & 3 & 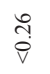 & $\tilde{\hat{v}}$ & 3 & $\ddot{\hat{v}}$ & 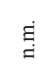 & तે & \\
\hline$\stackrel{0}{\frac{0}{10}}$ & 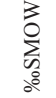 & $\stackrel{\circ}{i}$ & $\stackrel{g}{g}$ & $\begin{array}{l}\infty \\
\infty \\
\infty \\
i\end{array}$ & $\dot{\phi}_{i}$ & $\underset{\substack{\infty \\
\infty}}{\infty}$ & 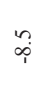 & 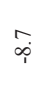 & $\begin{array}{l}\infty \\
\phi_{i}^{j} \\
i\end{array}$ & 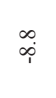 & $\rho_{\dot{p}}$ & $\stackrel{\Xi}{g}$ & $\hat{\phi}_{\hat{i}}$ & 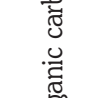 \\
\hline :0 & 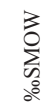 & مُ & $\stackrel{\Xi}{\Xi}$ & $\begin{array}{l}\stackrel{\infty}{\infty} \\
i \\
i\end{array}$ & تُ & $\begin{array}{l}n \\
\infty \\
i \\
i\end{array}$ & $\stackrel{+}{\vec{b}}$ & 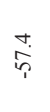 & ثُ & : & تَّ & $\stackrel{\Xi}{\Xi}$ & 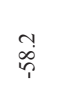 & 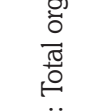 \\
\hline 高 & $\underset{\mathrm{b}}{\Xi}$ & $\stackrel{b}{\dot{b}}$ & $\dot{\Xi}$ & $\stackrel{n}{\stackrel{b}{\dot{v}}}$ & $\begin{array}{l}\ddot{0} \\
\dot{\nabla}\end{array}$ & 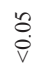 & $\stackrel{n}{\dot{v}}$ & $\stackrel{n}{\dot{v}}$ & 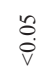 & 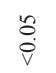 & $\stackrel{\Xi}{\Xi}$ & $\stackrel{\text { ò }}{\dot{\theta}}$ & $\begin{array}{l}\stackrel{n}{\dot{v}} \\
\stackrel{0}{0}\end{array}$ & $\underset{\ominus}{\ddot{O}}$ \\
\hline 窇语 & 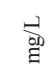 & $\stackrel{\infty}{\circ}$ & $\dot{\Xi}$ & $\stackrel{8}{\circ}$ & శ్ & $\begin{array}{l}\text { Ĩ } \\
\stackrel{0}{0}\end{array}$ & तु & $\vec{\delta}$ & $\overrightarrow{\mathrm{d}}$ & $\begin{array}{l}0 \\
\stackrel{0}{0} \\
0\end{array}$ & 兘 & 营 & $\stackrel{8}{\circ}$ & 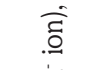 \\
\hline $\bar{\varangle}$ & 总 & $\frac{8}{\circ}$ & $\stackrel{\Xi}{g}$ & $\begin{array}{l}\infty \\
0 \\
0 \\
0\end{array}$ & 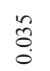 & ָิ & $\begin{array}{l}0 \\
\text { : } \\
0\end{array}$ & 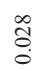 & $\begin{array}{l}\infty \\
\stackrel{0}{0} \\
0\end{array}$ & $\begin{array}{c}\stackrel{\infty}{\infty} \\
\stackrel{\infty}{0}\end{array}$ & $\ddot{g}$ & 号 & $\begin{array}{l}\text { o } \\
\text { dे } \\
0\end{array}$ & $\begin{array}{l}\delta^{\infty} \\
\text { I. }\end{array}$ \\
\hline$\vec{\omega}$ & 嶉 & $\vec{\infty}$ & $\hat{\omega}$ & in & $\stackrel{\infty}{\circ}$ & $\stackrel{?}{2}$ & $\stackrel{n}{n}$ & $\stackrel{\infty}{\infty}$ & $\stackrel{0}{\infty}$ & $\ddot{q}$ & $\infty_{\infty}^{\circ}$ & $\stackrel{\infty}{i}$ & $\stackrel{?}{2}$ & . \\
\hline 产 & 蚝 & $\tilde{\nabla}$ & $\tilde{\nabla}$ & $\tilde{\nabla}$ & $\tilde{\nabla}$ & $\tilde{v}$ & $\tilde{\nabla}$ & $\tilde{\nabla}$ & $\tilde{\nabla}$ & $\tilde{\nabla}$ & $\tilde{\nabla}$ & $\tilde{\nabla}$ & $\tilde{\nabla}$ & \\
\hline$\dot{\omega}$ & 㔖 & $\overline{\vec{v}}$ & స్ & $\stackrel{\infty}{\infty}$ & $\stackrel{\leftrightarrow}{\square}$ & $\stackrel{\leftrightarrow}{\rightarrow}$ & $\stackrel{\vec{t}}{\mathrm{i}}$ & 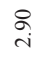 & $\overline{\vec{v}}$ & ชุ & $\overline{\vec{v}}$ & $\overline{\vec{v}}$ & $\hat{o}$ & 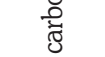 \\
\hline$\dot{0}$ & 总 & $\hat{v}$ & $\hat{v}$ & $\hat{\vec{v}}$ & $\tilde{\tilde{v}}$ & $\hat{\tilde{v}}$ & $\hat{\tilde{v}}$ & $\hat{\vec{v}}$ & $\stackrel{\tilde{v}}{v}$ & $\hat{\tilde{v}}$ & $\hat{\tilde{v}}$ & $\tilde{\tilde{v}}$ & $\hat{\vec{v}}$ & . \\
\hline$\dot{\rho}^{-\prime}$ & 总 & $\tilde{\nabla}$ & $\tilde{\nabla}$ & $\tilde{\nabla}$ & $\tilde{v}$ & $\tilde{\nabla}$ & $\tilde{v}$ & $\tilde{\tilde{V}}$ & $\tilde{\tilde{v}}$ & $\tilde{\tilde{v}}$ & $\tilde{\tilde{v}}$ & $\tilde{v}$ & $\tilde{v}$ & 芯 \\
\hline$\dot{U}$ & $\stackrel{\vec{D}}{\mathrm{D}}$ & $\stackrel{n}{\stackrel{n}{s}}$ & $\begin{array}{l}\stackrel{\partial}{\infty} \\
\stackrel{\infty}{-}\end{array}$ & नें & 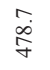 & तें & $\begin{array}{l}\tilde{Z} \\
\text { ָे }\end{array}$ & 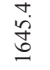 & $\underset{n}{n}$ & $m_{\infty}^{3}$ & $\hat{n}$ & 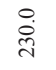 & 高 & $\begin{array}{l}\vec{D} \\
\frac{D}{0}\end{array}$ \\
\hline in & 蟠 & $\infty$ & $\vec{\infty}$ & $\stackrel{\circ}{i}$ & is & $\stackrel{\infty}{\infty}$ & $\bar{i}$ & 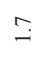 & $\hat{\infty}$ & $\stackrel{9}{=}$ & $\stackrel{\circ}{\varrho}$ & $\vec{\infty}$ & ถี & 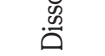 \\
\hline$\dot{n}$ & 总 & r & $\dot{g}$ & $n$ & 0 & ชี & $\stackrel{\infty}{\infty}$ & $\hat{o}$ & $\stackrel{a}{0}$ & $\underset{f}{g}$ & $\stackrel{\Xi}{\Xi}$ & 总 & $\stackrel{\text { Oे }}{0}$ & $\ddot{0}$ \\
\hline $\begin{array}{l}\dot{d}^{+} \\
\dot{n}^{+}\end{array}$ & 焉 & $\stackrel{+}{\vec{v}}$ & $\stackrel{0}{\circ}$ & $\therefore$ & $\stackrel{t}{\circ}$ & $\stackrel{+}{\dot{V}}$ & $\stackrel{t}{\vec{v}}$ & $\stackrel{t}{\vec{V}}$ & $\infty_{0}^{\infty}$ & $\underset{\infty}{+}$ & $n$ & $\stackrel{\circ}{\circ}$ & $\stackrel{\circ}{\circ}$ & हే \\
\hline$\underset{\wp}{\circlearrowright}$ & 焉 & $\stackrel{\circ}{i}$ & $\Xi$ & $\stackrel{\circ}{-}$ & i & $\stackrel{\circ}{i}$ & $\stackrel{\circ}{+}$ & $\stackrel{\infty}{\sim}$ & $\vec{v}$ & $\stackrel{\infty}{i}$ & ナ & N & $\stackrel{\circ}{+}$ & ) \\
\hline 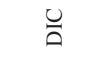 & 总 & $\stackrel{\circ}{+}$ & స̃ & $\stackrel{\infty}{\circ}$ & $\subsetneq$ & ? & $\stackrel{\circ}{\circ}$ & $\vec{v}$ & $\stackrel{\circ}{\circ}$ & $\stackrel{\circ}{\circ}$ & in & $\stackrel{\circ}{+}$ & $:$ & 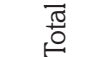 \\
\hline$\circlearrowright$ & 总 & : & $\stackrel{?}{+}$ & $\stackrel{+}{i}$ & ले & $\stackrel{\circ}{r}$ & $\stackrel{\circ}{+}$ & $\stackrel{\infty}{+}$ & 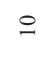 & $\stackrel{\square}{\sigma}$ & $\stackrel{\sigma}{\circ}$ & iे & in & $\ddot{\ominus}$ \\
\hline 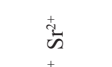 & 总 & $\tilde{\hat{v}}$ & $\dot{\Xi}$ & $\stackrel{\tilde{v}}{\vec{v}}$ & $\hat{\tilde{v}}$ & $\hat{\tilde{v}}$ & $\tilde{\hat{v}}$ & $\hat{\tilde{v}}$ & $\hat{\tilde{v}}$ & $\hat{\tilde{v}}$ & $\stackrel{\Xi}{\sharp}$ & $\stackrel{\tilde{v}}{\hat{v}}$ & $\stackrel{\circ}{\circ}$ & $\bar{\Xi}$ \\
\hline$\frac{b_{0}^{+}}{2}$ & 焉 & $\overrightarrow{\vec{v}}$ & $\overrightarrow{\dot{v}}$ & $=$ & $=$ & $\stackrel{t}{\circ}$ & $\overrightarrow{0}$ & $\overrightarrow{\dot{v}}$ & $\overrightarrow{\dot{v}}$ & $\overrightarrow{\dot{v}}$ & $\overrightarrow{\dot{v}}$ & $\overrightarrow{\hat{v}}$ & $\overrightarrow{\dot{v}}$ & 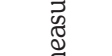 \\
\hline 瓶 & 㔖 & $\vec{D}$ & $\overrightarrow{i j}$ & 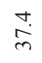 & $\vec{f}$ & ल्ల్ల & 交 & $\begin{array}{l}\text { 遖 } \\
0 \\
0\end{array}$ & iे & $\Xi$ & bे & $\underset{\substack{\sim \\
\sim}}{\sim}$ & $\underset{\infty}{\infty}$ & $\begin{array}{l}\underline{\xi} \\
\stackrel{0}{o}\end{array}$ \\
\hline \pm & 总 & ó & $\stackrel{m}{=}$ & $\stackrel{+}{\sigma}$ & $\ddot{y}$ & $\vec{m}$ & $n$ & $\stackrel{\leftrightarrow}{+}$ & ? & oे & 3 & oे & ช̃ & \\
\hline 艺 & $\stackrel{\overrightarrow{b D}}{\Xi}$ & $\stackrel{\text { }}{\stackrel{\Xi}{\Xi}}$ & $\vec{\infty}$ & $\underset{\Phi}{\vec{\Phi}}$ & 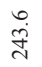 & वे & 苨 & స్ & $\begin{array}{l}r \\
\infty \\
i\end{array}$ & $\overrightarrow{\dot{D}}$ & 苞 & $\stackrel{\square}{\simeq}$ & t & \\
\hline 岸 & ह & $\stackrel{\circ}{\circ}$ & $\stackrel{\circ}{\circ}$ & $\stackrel{\circ}{i}$ & $\stackrel{\circ}{\dot{\Xi}}$ & 얼 & $\begin{array}{l}\ddot{\text { aे }} \\
\ddot{a}\end{array}$ & $\begin{array}{l}\text { iे } \\
\text { in }\end{array}$ & in & $\begin{array}{l}\text { o } \\
\stackrel{\alpha}{q}\end{array}$ & $\hat{\mathrm{j}}$ & $\overline{8}$ & $\mathcal{F}$ & \\
\hline$\frac{*}{H}$ & 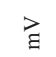 & 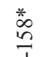 & $\ddot{r}$ & $\ddot{p}_{i}$ & $\fallingdotseq$ & ஜุ & : & $\tilde{i}$ & $\stackrel{*}{*}$ & 总 & $\stackrel{1}{t}$ & $\infty$ & ๙ & $\Xi$ \\
\hline 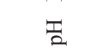 & & $\dot{\alpha}_{\dot{\infty}}$ & $\underset{\infty}{\infty}$ & $\hat{\infty}$ & 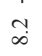 & $\underset{\infty}{+}$ & $\vec{\infty}$ & $n$ & a & $\dot{\alpha}$ & $\hat{\infty}$ & $a_{\infty}$ & $\hat{\infty}$ & 品 \\
\hline 'dшәد & 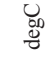 & di & $\overline{\mathrm{d}}$ & त्र & i̇ & $\stackrel{+}{\infty}$ & $\stackrel{m}{d}$ & $\overline{\tilde{n}}$ & $\stackrel{\circ}{\circ}$ & $\stackrel{\text { i }}{3}$ & ঙ.ं. & $\stackrel{n}{=}$ & $\underset{\sim}{*}$ & हू \\
\hline әџер & & $\stackrel{\text { సे }}{=}$ & ్ֻర్ర్ర & $\stackrel{+}{\dot{b}}$ & $\frac{\infty}{0 .}$ & ๙ุ & $\stackrel{2}{\ddot{n}}$ & $\stackrel{m}{\ddot{n}}$ & ঙิ & $\stackrel{2}{2}$ & రం. & $\stackrel{\circ}{\dot{f}}$ & के & \\
\hline ŝu!̣dures & & ఫ్సं & 密 & 总 & 离 & 离 & 离 & 离 & 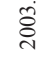 & 㤎 & 芯 & 离 & 突 & \\
\hline นо̣емәઇ日 & 产 & nุ. & $\frac{n}{a}$ & $\begin{array}{l}0 \\
0.0 \\
0\end{array}$ & $\frac{1}{c}$ & : & त्र & 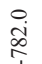 & 이 & $\stackrel{\circ}{\rightarrow}$ & $\vec{\sigma}$ & 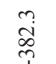 & 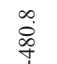 & 言 \\
\hline чүdәə & 高 & $\infty$ & $\stackrel{\infty}{\stackrel{0}{\varrho}}$ & $\dot{q}$ & 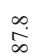 & m. & 3 & nู & f & $\stackrel{m}{8}$ & $\stackrel{\infty}{b}$ & $\therefore$ & $\stackrel{n}{n}$ & $\overline{\frac{\tilde{g}}{2}}$ \\
\hline & छ & ๙ & $\bar{m}$ & f & $i$ & F & से & 2 & $=$ & ส & 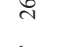 & in & : & है \\
\hline $\begin{array}{l}\text { poipau } \\
\text { sulddure }\end{array}$ & & $\Sigma$ & $\Xi$ & $\underline{2}$ & $\underline{E}$ & $\dot{E}$ & $\Xi$ & $\Sigma$ & 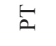 & $E$ & $\dot{2}$ & 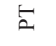 & $\Xi$ & $\tilde{\pi}$ \\
\hline Кธิороэ๐ & & 0 & 0 & 0 & 0 & 0 & 0 & 0 & 0 & 0 & 0 & 0 & 0 & 5 \\
\hline иоџ̣вэо | & & 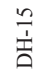 & $\stackrel{n}{ \pm}$ & 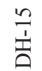 & $\stackrel{n}{\frac{n}{a}}$ & $\stackrel{n}{ \pm}$ & $\stackrel{n}{ \pm}$ & 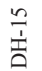 & $\begin{array}{l}\overrightarrow{\hat{N}} \\
\vec{\Sigma}\end{array}$ & $\begin{array}{l}\overline{\hat{N}} \\
\mathrm{\Sigma}\end{array}$ & $\overrightarrow{\hat{N}}$ & $\overrightarrow{\hat{N}}$ & $\overline{\hat{~}}$ & \\
\hline
\end{tabular}


Katsuhiro Hama. : Development of Site Characterization Technologies for Crystalline Rocks at Mizunami Underground Research Laboratory (MIU) - Surface-based Investigation Phase -
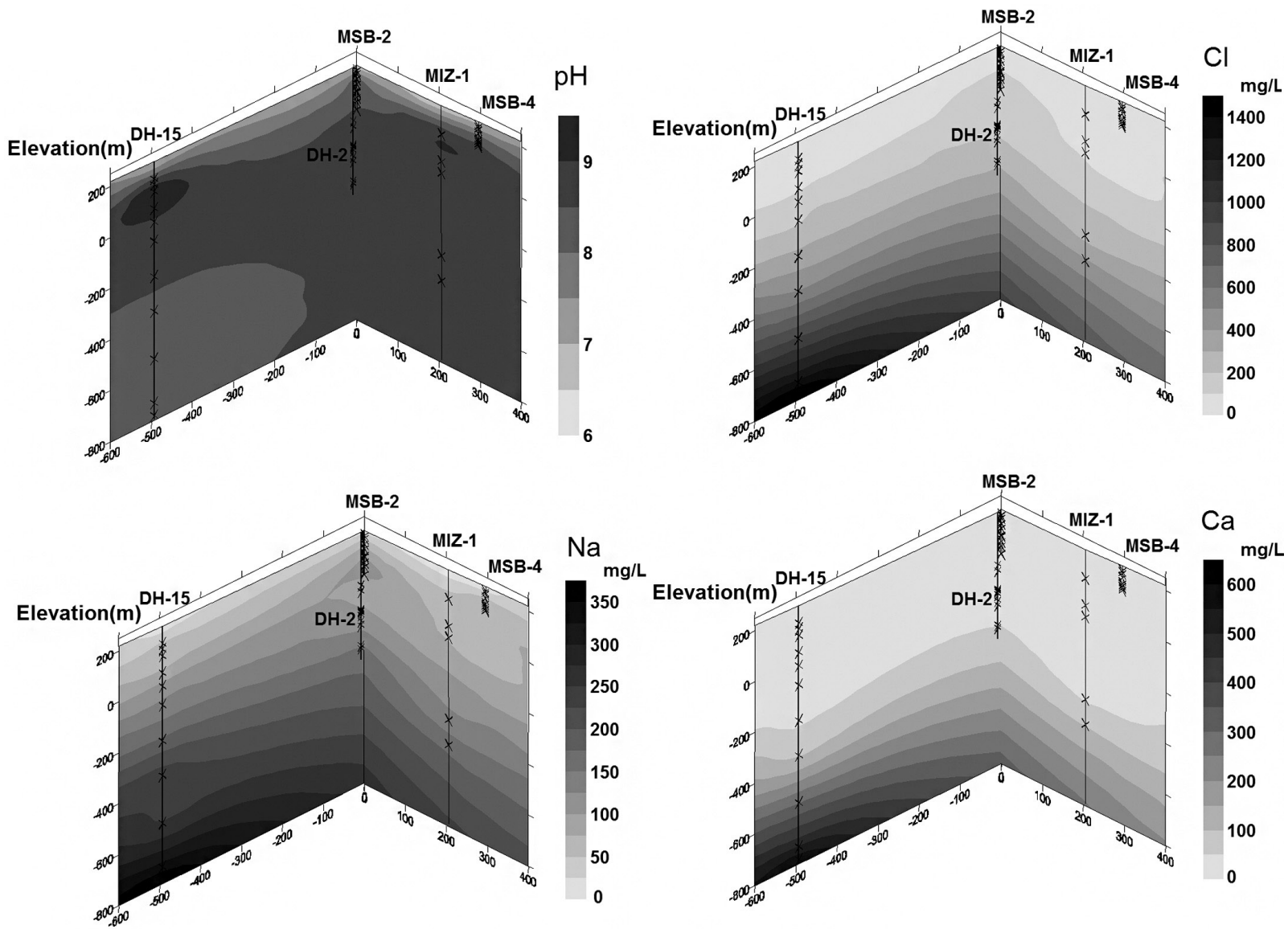

Fig. 11. Three-dimensional distribution of groundwater chemistry in the site scale.

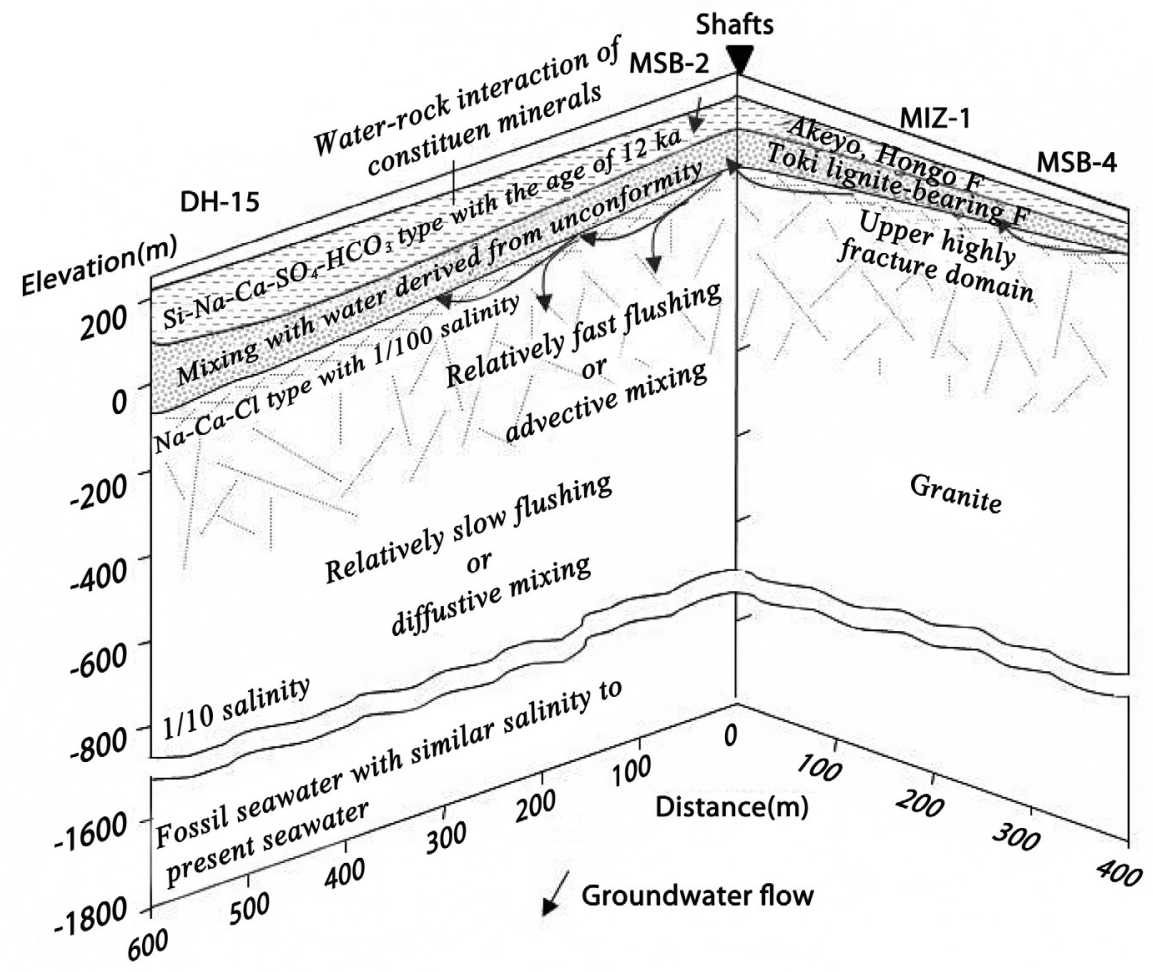

Fig. 12. Hydrochemical conceptual model in and around the MIU construction site. 
Katsuhiro Hama. : Development of Site Characterization Technologies for Crystalline Rocks at Mizunami Underground Research Laboratory (MIU) - Surface-based Investigation Phase -

sition $\left({ }^{2} \mathrm{H} /{ }^{1} \mathrm{H}\right.$, tritium, $\left.{ }^{18} \mathrm{O} /{ }^{16} \mathrm{O},{ }^{13} \mathrm{C} /{ }^{12} \mathrm{C},{ }^{14} \mathrm{C}\right)$ were determined to estimate the origin, residence time and chemical evolution process of the groundwater.

$\mathrm{Na}-\mathrm{Ca}-\mathrm{Cl}$ type groundwater with a salinity of approximately $2,500 \mathrm{mg} 1^{-1}$ (one tenth of the salinity of seawater) was found in the granite at a depth of approximately 1,000 meters in the site-scale area (Fig. 10). The $\mathrm{pH}$ value of the groundwater was almost always in the range of $8-9$ and this was consistent with the result predicted in Step 0 . As a result of a thermodynamic analysis using PHREEQ-C, calcite was found to be under-saturated to just saturated at almost all groundwater sampling points. Based on this result and microscopic observation of rock alteration, the water has a major $\mathrm{pH}$ buffering capacity due to dissolution/sedimentation reactions with carbonate minerals [8]. Measurement of redox potential (Eh) was conducted during pumping tests, although, it was difficult to obtain good quality data. However, based on mineral observations and the results of dissolved gas analysis, potential occurrence of redox reactions involving iron minerals, sulphur minerals and hydrogen sulphide gas was indicated. With regard to the origin and residence time based on measurements of ${ }^{14} \mathrm{C}$ and ${ }^{3} \mathrm{H}$ of the $\mathrm{Na}$ $\mathrm{Ca}-\mathrm{Cl}$ type groundwater, it was concluded from the isotope composition and the ratio of the dissolved chemical components that the groundwater was diluted from saline water that either originated from fossil seawater or from long-term water-rock reactions. Either way, the origin of the $\mathrm{Na}-\mathrm{Ca}-\mathrm{Cl}$ type groundwater will be different from $\mathrm{Na}-\mathrm{Ca}-\mathrm{HCO}_{3}$ type groundwater. However, the potential dilution could not be confirmed through investigations in this step, because the salinity of the groundwater was lower compared to that of seawater. Since the origin and residence time of groundwater are useful for validating the results of the groundwater flow analysis, this remains an issue for the investigations in Phase II and subsequent phases.

\subsection{Issues for Phase II investigation}

Based on the above results, the following can be identified as issues for Phase II and beyond:
- Testing of the hydrochemical model constructed based on the investigations in Phase I and the hydrochemical changes predicted based on the model through comparison with the results of chemical analyses of groundwater sampled in the underground facilities and of the monitoring of changes of groundwater chemistry due to the excavation of the underground facilities.

- Identification of the general processes and mechanisms involved in the changes in the hydrochemical and hydrogeological environments in and around the underground facilities, which may be induced by the facilities during their construction and operation, in order to clarify the capability of the geological environment to recover from human-induced hydrochemical disturbances, as well as for developing methods for predicting the time required for recovery and steady-state conditions after recovery. These techniques are indispensable for predicting recovery to a steady-state after the closure of a repository and the differences between this new steady-state and that before the excavation of the underground facilities. They will be extremely important for evaluating the uncertainties in various parameters used for the safety assessment and ensuring the reliability of the long-term safety assessment technology.

\section{Summary}

Thus, this paper summarizes geosynthesis procedures to investigate and assess the crystalline rock, and development of individual investigation and assessment methods. At the same time, technical findings and know-how which can serve as foundation to implementation of the disposal project were compiled. Also, this paper clarified the necessity for the Phase II and Phase III investigation by compiling unresolved issues during the Phase I investigation.

The results described in this paper will be utilized as technical knowledge of disposal technology and effectively used to enhance technical foundation which 
will support both the implementation and formulation of safety regulations.

\section{Acknowledgments}

I express our sincere thanks to the anonymous reviewer and researchers who assisted with data collection for this study and took the time to complete the investigation.

\section{REFERENCES}

[1] Nuclear Waste Management Organization of Japan: "Development of Repository Concepts for Volunteer Siting Environments", NUMO-TR-04-03 (2004).

[2] AECL: "Environmental Impact Statement on the Concept for Disposal of Canada's Nuclear Fuel Waste", Atomic Energy of Canada Limited, AECL10711, COG-93-1 (1994).

[3] Posiva: "The Final Disposal Facility for Spent Nuclear Fuel - Environmental Impact Assessment Report" (1999).

[4] DOE: "Final Environmental Impact Statement for a Geologic Repository for the Disposal of Spent Nuclear Fuel and High-Level Radioactive Waste at Yucca Mountain, Nye County, Nevada", U.S. Department of Energy, DOE/EIS-0250 (2002).

[5] Ota, K., Sato, T., Takeuchi, S., Iwatsuki, T., Amano, K., Saegusa, H., Matsuoka, T. and Onoe, H.: "Technical expertise gained from the surface-based investigations at the Tono area", Japan Nuclear Cycle Development Institute, JNC TN7400 2005023 (2005). (in Japanese)

[6] Nagra: "Geosynthese Wellenberg 1996, Ergebnisse der Untersuchungsphasen I und II", Nagra Technical Report NTB96-01 (1997).

[7] Furue, R., Iwatsuki, T. Mizuno, T. and Mie, H.: "Data Book on Groundwater Chemistry in the Tono Area", Japan Nuclear Cycle Development Institute, JNC TN 7450 2003-001 (2003).

[8] Iwatsuki, T., Furue, R., Mie, H., Ioka, S. and Mizuno, T.: "Hydrochemical baseline condition of groundwater at the Mizunami underground research laboratory (MIU)", Applied Geochemistry, 20, pp.2283-2302 (2005).

[9] Saegusa, H and Matsuoka, T. (Eds.) : Final Report on the Surface-based Investigation (Phase I) at the Mizunami Underground Laboratory Project, JAEA R\&D report, JAEA-Research 2010-067 (2010). 